13 Schouten JSAG, van den Ouweland FA, Valkenburg HA. Natural menopause, oophorectomy, hysterectomy and the risk of osteoarthritis in dip joints. Scand $\varsubsetneqq$ Rheumatol 1992; 21:196-200.

14 Anderson J, Felson DT. Factors associated with osteoarthritis of the knee in the First National Health and Nutrition Examination Survey (NHANES-1). Am $\mathcal{f}$ Epidemiol 1988;128:179-89.

15 Tepper S, Hochberg MC. Factors associated with hip osteoarthritis: data from the First National Health and Nutrition Examination Survey (NHANES-1). Am $\mathcal{f}$ Epidemiol 1993;137:1081-8.

16 Hochberg MC, Powell-Threets, SK, Nevitt MC, Lane NE, Cummings SR, Pressman AR, et al. Reproductive and gynaecologic history and osteoarthritis of the hip in elderly women: data from the study of osteoporotic fractures. Arthritis Rheum 1995;38(suppl):S396.

17 Spector TD, Brown GC, Silman AJ. Increased rates of previous hysterectomy and gynaecological operations in women with osteoarthritis. BMF 1988;297:899-901.

18 Spector TD, Hart DJ, Brown P, Almeyda J, Dacre JE, Doyle DV, et al. Frequency of osteoarthritis in hysterectomized women. $\mathcal{f}$ Rheumatol 1991;18:1877-83.

19 Lethbridge-Cejku M, Hochberg MC, Scott WW, Reichle R, Plato CC, Roy TA, et al. Lack of association of reproductive and gynaecologic factors with radiographic features of osteoarthritis of the knee in postmenopausal women: Data from the Baltimore Longitudinal Study of Aging. Arthritis Rheum 1995;38(suppl):S223.

\title{
Sex hormones and the risk of osteoarthritis in women: epidemiological evidence
}

\author{
Michael C Nevitt, David T Felson
}

Current concepts of the pathogenesis of osteoarthritis suggest a role for both systemic predisposition and site specific mechanical factors. ${ }^{1}$ Sex hormones have long been considered a possible factor in the systemic predisposition to osteoarthritis, especially in women. ${ }^{2-5}$ There are several lines of epidemiological evidence suggesting that sex hormones, primarily oestrogen, play a role in osteoarthritis. These include a female excess in the prevalence and incidence of osteoarthritis that begins around the time of the menopause, and the association of prevalent osteoarthritis with possible markers of endogenous sex hormone exposure, including gynaecological surgery (reviewed elsewhere in this supplement) bone mass, and obesity. In a provocative review, Spector and Campion ${ }^{4}$ proposed that much of this evidence is consistent with the hypothesis that women with a greater exposure to endogenous oestrogen are predisposed to generalised osteoarthritis. On the other hand, studies that assess serum sex hormone levels in women with osteoarthritis are inconclusive. There is also a growing body of evidence to suggest that postmenopausal oestrogen replacement may protect against large joint osteoarthritis. It is possible that the effect of sex hormone exposure in osteoarthritis varies by menopausal status and stage in the extended pathogenesis of osteoarthritis.

\section{Menopause}

The prevalence of osteoarthritis in the hand, hip, and knee increases rapidly with age, beginning at about the age of 40-50 years in women, but less so in men, so that before the age of 50 , men have a higher prevalence of disease than women, but after 50 women have a higher prevalence, and the incidence and sex differences increase with age. ${ }^{6-10}$ Older women are also more likely to report joint symptoms for the same level of radiographic severity of knee osteoarthritis ${ }^{11}$ and have more rapid progression of hip osteoarthritis than men. ${ }^{12}$ Some investigators have suggested that women develop "menopausal arthritis" which consists of rapidly progressing osteoarthritis in the hand at the time of menopause. ${ }^{2313}$ Menopausal arthritis has been linked to generalised osteoarthritis with Heberden's nodes ${ }^{313}$ which may be more common in women..$^{10}$ However, attempts to establish a temporal relationship between onset of generalised osteoarthritis and the menopause in individuals have been inconclusive. ${ }^{3}$ Nevertheless, these patterns are broadly consistent with a role for postmenopausal hormone deficiency in increasing the risk or severity of osteoarthritis in women. In diseases such as heart disease, gout, and osteoporosis in which, like osteoarthritis, women's risk of disease rises dramatically after the menopause, oestrogen loss has been strongly implicated in disease risk.

Menopausal changes in systemic hormone levels are complex and include a profound longterm decline in oestradiol concentrations, lesser declines in oestrone and androgen concentrations, increased ratios of oestrone and testosterone to oestradiol, and decreases in sex hormone binding globulin, as well as increased short term fluctuations in cyclical levels of several hormones during the perimenopausal period. ${ }^{14}{ }^{15}$ Hot flushes, the most common menopausal symptom, are strongly associated with musculoskeletal pain ${ }^{16}$ and appear to be linked to rapid fluctuations in serum oestradiol concentrations. ${ }^{15}$ Spector and Campion ${ }^{4}$ proposed that early perimenopausal declines in progesterone levels result in a temporary increase in levels of unopposed oestrogen which may predispose to osteoarthritis. Whether short term hormonal imbalances and fluctuations or permanent declines in hormone concentrations contribute to the surge in osteoarthritis risk which begins around the age of the menopause remains to be determined.

\section{Bone density and obesity}

The inverse relation of osteoarthritis with osteoporosis and the increased risk of osteoarthritis with obesity both suggest a possible role for

oestrogen in osteoarthritis pathogenesis. ${ }^{4}$ Oes-
Boston University, Massachusetts, USA D T Felson 
trogen regulates bone metabolism, and oestrogen deficiency causes bone loss in premenopausal and postmenopausal women ${ }^{17}$; a high bone mass in postmenopausal women is, in part, a marker for a greater lifetime exposure to oestrogen. ${ }^{18}$ Postmenopausal women with knee, hip, hand, and multijoint osteoarthritis have an increased bone mineral density that is not explained by obesity. ${ }^{19-22}$ This increased bone density is not due to slower postmenopausal bone loss in women with osteoarthritis $^{22}$ and may predate the menopause. ${ }^{21}$ The association of osteoarthritis with high bone density may reflect increased biomechanical stress on cartilage in women with high bone mass ${ }^{23}$ due to greater oestrogen exposure or could be due to a direct adverse effect of oestrogen on cartilage. On the other hand, high bone mass could be related primarily to osteophyte formation, ${ }^{1920}$ and the co-occurrence of these two features in "bone formers" may be explained by increased levels of bone or cartilage growth factor. ${ }^{24}$

Obesity is also associated with higher levels of endogenous oestrogen in postmenopausal women. ${ }^{25}$ Obesity increases the risk of knee, hip, and hand osteoarthritis in women. (Felson DT, this issue, $p$ 669) but whether this is due to the mechanical effect of weight on cartilage, higher estrogen levels or other systemic correlates of obesity is not known. ${ }^{26}$

\section{Endogenous hormone concentrations}

Two epidemiological studies have examined the relation of serum levels of sex hormones and osteoarthritis in postmenopausal women, with inconclusive results. Spector $e t a l^{77}$ studied early postmenopausal women with hand osteoarthritis defined by Heberden's nodes

Epidemiological studies of postmenopausal oestrogen replacement therapy (ORT) and osteoarthritis $(O A)$

\begin{tabular}{|c|c|c|c|c|c|}
\hline Author/Year & $N$ & Design & foint(s) & $\begin{array}{l}\text { Definition of } \\
O A\end{array}$ & Results* \\
\hline $\begin{array}{l}\text { Nevitt, et al } 1994 \\
\text { (29) }\end{array}$ & 4366 & $\begin{array}{l}\text { Cohort } \\
\text { Cross-sect }\end{array}$ & Hip & $\begin{array}{l}x \text { ray OA, } \\
\text { Symptomatic } \\
\text { OA }\end{array}$ & $\begin{array}{l}8.9 \% \text { of current ORT } \\
\text { users with OA } v 12.9 \% \\
\text { non-users; adjusted } \\
\text { OR }=0.7(0.5,0.9) .\end{array}$ \\
\hline $\begin{array}{l}\text { Hannan et al } \\
1990 \text { (30) }\end{array}$ & 831 & $\begin{array}{l}\text { Cohort } \\
\text { Cross-sect }\end{array}$ & Knee & $x$ ray OA & $\begin{array}{l}\geq 2 \text { exams of ORT use, } \\
\text { adjusted OR of } x \text { ray } \\
O A=0.7(0.4,1.2) \\
\text { compared with never } \\
\text { users. }\end{array}$ \\
\hline $\begin{array}{l}\text { Wolfe et al } 1994 \\
\quad(46)\end{array}$ & 1329 & $\begin{array}{l}\text { Case-control } \\
\text { Cross-sect }\end{array}$ & $\begin{array}{l}\text { Hip \& } \\
\text { knee }\end{array}$ & $\begin{array}{l}\text { Symptomatic } \\
\text { OA }\end{array}$ & $\begin{array}{l}\text { Ever use of ORT } \\
\text { associated with slight } \\
\text { reduction of } O A \\
\text { prevalence: adjusted } \\
\text { OR }=0.9(0.7,1.2) . \\
\text { ORT users with milder } \\
x \text { ray OA than } \\
\text { non-users. }\end{array}$ \\
\hline $\begin{array}{c}\text { Samanta et al } \\
1993(47)\end{array}$ & 690 & $\begin{array}{l}\text { Case-control } \\
\text { Cross-sect }\end{array}$ & $\begin{array}{l}\text { Large joint } \\
\text { (knee \& } \\
\text { hip) }\end{array}$ & $\begin{array}{l}\text { Symptomatic } \\
\text { OA }\end{array}$ & $\begin{array}{l}\text { Ever use of ORT } \\
\text { associated with } \\
\text { decreased rate of large } \\
\text { joint OA (crude OR = } \\
0.3 \text { Hand }(0.1,1.4) \text { ) } \\
\text { and decreased rate of } \\
\text { hand OA (crude OR = } \\
0.6(0.2,1.9) \text {. }\end{array}$ \\
\hline $\begin{array}{l}\text { Zhang et al } 1995 \\
\text { (31) }\end{array}$ & 557 & $\begin{array}{l}\text { Cohort } \\
\text { Longitudinal }\end{array}$ & Knee & $\begin{array}{l}x \text { ray OA } \\
\text { Incident } \\
\text { progressive } \\
\text { OA }\end{array}$ & $\begin{array}{l}4 \% \text { of current ORT } \\
\text { users with OA } v 19 \% \\
\text { non-users; adjusted } \\
\text { OR }=0.3(0.01,1.2)\end{array}$ \\
\hline
\end{tabular}

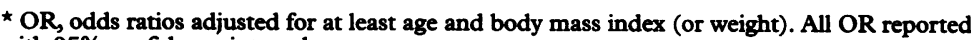
with $95 \%$ confidence intervals.

Cross-sect, cross sectional. and found decreased levels of sex hormone binding globulin, possibly indicating higher levels of circulating free oestrogens and androgens, but no difference in oestradiol or testosterone concentrations. Cauley and colleagues $^{28}$ found no association of radiographic hand osteoarthritis with serum concentrations of oestrone, testosterone, or androstenedione in elderly Caucasian women. There are no published studies of serum sex hormone concentrations and knee or hip osteoarthritis.

\section{Exogenous sex hormones}

Some of the most intriguing evidence linking female sex hormones with osteoarthritis comes from studies examining the risk of osteoarthritis in women on postmenopausal oestrogen replacement therapy (ORT). Several recent epidemiological studies have found that ORT is associated with a lower than expected risk of knee and hip osteoarthritis (table). Four studies have evaluated prevalent disease (two investigated primarily radiographic disease), and one examined incident and progressive radiographic disease. All have shown an inverse association between ORT use and the risk of osteoarthritis, although in one study the odds ratio was close to unity (0.9). A meta-analysis (unpublished data) of the four prevalence studies (using a combined endpoint of knee and hip osteoarthritis and a fixed effects approach) shows a pooled odds ratio of 0.76 ( $95 \%$ confidence interval 0.63 to 0.91 ). In the two largest prevalence studies, the inverse association was stronger when analysis was restricted to more severe or bilateral radiographic osteoarthritis, ${ }^{2930}$ and one study found a non-significant trend (odds ratio for current use $=0.6$ ) for a lower risk of symptomatic moderate to severe disease. ${ }^{29}$ More recently, Zhang et al reported that current ORT users in the Framingham study have an adjusted odds of 0.3 (95\% confidence interval 0.1 to $1.2, \mathrm{P}=0.07$ ) of incident or progressive radiographic knee osteoarthritis during eight years of follow up. ${ }^{31}$ A stronger inverse association with disease among women receiving long term ORT was found for both prevalent radiographic osteoarthritis (10 years of use $v$ one to nine $)^{2930}$ and incident osteoarthritis (five years of use $v$ one to five). ${ }^{30}$ In contrast, another recent study found that current use of ORT was associated with a $40 \%$ non-significant increase, and long term ORT use with no difference, in the risk for a combined endpoint of incident clinical osteoarthritis of the knee, hip, or hand..$^{32}$

Three studies ${ }^{29-31}$ included adjustments for important confounding variables, including obesity, physical activity, smoking, reproductive history, and ovariectomy. Women with osteoporosis are more likely to be prescribed oestrogen, and osteoporosis may protect against osteoarthritis ${ }^{23}$; two studies adjusted for markers of osteoporosis. ${ }^{29}$ Despite these attempts to adjust for confounding variables, women who use, and remain on, ORT differ in many ways from those who choose not to use 
oestrogen $^{33}$ and this could explain the apparent protective effect of oestrogen.

Studies of the effect of oestrogen administration in animal models of osteoarthritis have been inconsistent. One study found that subcutaneous injections of oestradiol reduced the development of osteoarthritis lesions in a male mouse model. ${ }^{34}$ Recently it was shown that ovariectomised sheep develop increased vulnerability of cartilage to shear and compression stress, but those treated with oestrogen do not develop such cartilage changes. ${ }^{33}$ However, in meniscectomised female rabbits, Rosner and colleagues found that subcutaneous oestradiol administration increased, while that of the oestrogen agonist/antagonist tamoxifen decreased, erosive lesions in cartilage in both ovariectomised and non-ovariectomised animals. ${ }^{5}$ Injection of oestradiol into the knees of ovariectomised rabbits has also been reported to produce osteoarthritis-like cartilage lesions, although the local irritating effect is unknown and the dose used was suprapharmacological..$^{35}$

\section{Mechanisms}

Oestrogen could effect osteoarthritis through cytokines and growth factors which have a potential role in cartilage metabolism. For example, the cytokines interleukin (IL)-1 and tumour necrosis factor $\alpha$ (TNF- $\alpha$ ), which can be produced by joint tissue, potentiate the production and activation of enzymes which degrade cartilage matrix. ${ }^{36}{ }^{37}$ Synthesis of IL-6 by articular chondrocytes may also play a role in cartilage metabolism, though this is uncertain. ${ }^{37}$ The effect of oestrogen on bone metabolism appears to be mediated in part by these cytokines. ${ }^{38}{ }^{39}$ Oestrogen receptors are found in articular cartilage $e^{40}$ and one study suggests that IL-1 and IL-6 may mediate an effect of oestrogen on cartilage metabolism. ${ }^{41}$ The growth factors insulin-like growth factor 1 (IGF-1) and transforming growth factor $\beta$ (TGF- $\beta$ ) may be involved in the synthesis and repair of cartilage matrix ${ }^{42}$; oestrogen has complex effects on the growth hormone-growth factor axis. ${ }^{17}$ 43-44

Oestrogen may also influence the development of osteoarthritis through its effect on bone metabolism. Higher bone mass resulting from greater oestrogen exposure could cause increased mechanical stress on cartilage during joint loading. ${ }^{23}$ Progressive cartilage degradation and rapid subchondral bone turnover are closely linked in osteoarthritis. ${ }^{45}$ ORT reduces bone turnover in postmenopausal women ${ }^{17}$ and could help stabilise osteoarthritis by slowing subchondral bone remodelling.

Other possible mechanisms by which oestrogen could influence the risk of osteoarthritis include protection against vascular defects in subchondral bone, greater neuromuscular protection against excessive joint loading, and through its antioxidant potential.

\section{Conclusion}

The evidence from epidemiological studies of the association of osteoarthritis with factors related to sex hormone exposure in women is conflicting and often difficult to interpret. There are many potential sources of bias and confounding in existing studies, which may not be adequately controlled for in the design or analysis. The hormonal correlates of the menopause and other potential markers of endogenous hormone exposure are complex, making implication of any specific hormonal changes in osteoarthritis risk uncertain. The natural history of osteoarthritis is not well enough understood, at present, to gauge the importance in older postmenopausal women of exposure to endogenous hormones 10 to 20 years previously. It is possible that oestrogen exposure has different effects depending on menopausal status or stages in the pathogenesis of osteoarthritis. High levels of oestrogen may act to increase the risk of disease in premenopausal women, either directly or through a higher bone mass, but slow the development or progression of disease in postmenopausal and elderly women. Increasing numbers of studies suggest that women on ORT have a lower than expected risk of radiographic osteoarthritis of the knee and hip. Clarifying the effect of postmenopausal hormone replacement therapy on osteoarthritis will probably require a randomised trial. Further epidemiological, clinical, and biochemical studies of the role of sex hormones in osteoarthritis among women is warranted.

Supported by US Public Health Service grant 1-RO1AG05407

1 Dieppe $\mathrm{P}$. The classification and diagnosis of osteoarthritis In: Kuettner KE, Goldberg VM, eds. Osteoarthritic disorders. Rosemont, IL: Amercan Academy of Orthopedic Surgeons, 1995:5-12.

2 Cecil RL, Archer BH. Classification and treatment of chronic arthritis. $\mathcal{f} A M A$ 1926;87:741-6.

3 Kellgren $J H$, Moore R. Generalized osteoarthritis and Heberden's nodes. BMF 1952;i:181-7.

4 Spector T, Campion GC. Generalized osteoarthritis is a hormonally mediated disease. Ann Rheum Dis 1989 48:256-61.

5 Rosner I, Goldberg VM, Moskowitz RW. Estrogens and osteoarthritis. Clin Orthop Rel Res 1986;213:77-83.

6 Felson DT. Epidemiology of hip and knee osteoarthritis. Epidemiol Rev 1988;10:1- 28.

7 Van Saase JLCM, Van Romunde LKJ, Cats A, Vandenbroucke JP, Valkenburg HA. Epidemiology of osteoarthritis: Zoetermeer survey. Comparison of radiological osteoarthritis in a Dutch population with that in 10 other populations. Ann Rheum Dis 1989;48:271-80.

8 Lawrence RC, Hochberg MC, Kelsey JL, McDuffie FC, Medsger TA, Felts WR, et al. Estimates of the prevalence of selected arthritic and musculoskeletal diseases in the United States. ₹ Rheumatol 1989;16:427-41.

9 Oliveria SA, Felson DT, Reed JI, Cirillo PA, Walker AM. Incidence of symptomatic hand, hip, and knee osteoarthritis among paiteints in a health maintenance organization. tis among paiteints in a health main

10 Lawrence JS. Osteo-arthrosis. In: Rheumatism in populations. London: Heinemann, 1977:98-115.

11 Felson DT, Naimark A, Anderson J, Kazis L, Castelli W, Meenan RF. The prevalence of knee osteoarthritis in the elderly. Arthritis Rheum 1987;30:914-8.

12 Ledingham J, Dawson S, Preston B, Milligan G, Doherty $M$. Radiographic progression of hospital referred osteoarthritis of the hip. Ann Rheum Dis 1993;52:263-7.

13 Stecher RM, Beard EE, Hersh HH. Development of Heberden's nodes and menopause. $f$ Lab Clin Med 1949; 34:1193-202.

14 Schiff I. Menopause. In: Becker KL, ed. Principles and practices of endocrinology and metabolism. Philadelphia: JB Lippincot, 1990:826-33.

15 Agarwal SK, Judd HL. Management of menopause. In: Riggs BL, Melton LJ, eds. Osteoporosis: etiology, diagnosis and management, 2nd ed. Philadelphia: Lippincott-Raven 1995:351-70.

16 Oldenhave A, Jaszmann L, Haspels AA, Everaerd W. Impact of the climacteric on well-being: a survey based on 5213 women 39-60 years old. Am f Obstet Gymecol 1993; 168:772-80. 
17 Lindsay R. Estrogen deficiency. In: Riggs BL, Melton LJ, eds. Osteoponosis: etiology, diagnosis and management, 2nd ed. Philadelphia: Lippincott-Raven, 1995:133-60.

18 Kritz-Silverstein DK, Barret-Connor E. Early menopause, number of reproductive years, and bone mineral density in number of reproductive years, and bone mineral density in
postmenopausal women. Am f Pub Health 1993;83:983-8.

19 Nevitt MC, Lane NE, Scott JC, Hochberg MC, Pressman AR, Genant HK et al. Radiographic osteoarthritis of the hip and bone mineral density. Arthritis Rheum (in press).

20 Hannan MT, Anderson JJ, Zhang Y, Levy D, Felson DT. Bone mineral density and knee osteoarthritis in elderly men and women: the Framingham Study. Arthritis Rheum 1993;36:1671-80.

21 Hart D, Mootooswamy I, Doyle D, Spector T. The relationship between osteoarthritis and osteoporosis in the general population: the Chingford Study. Ann Rheum Dis (in press).

22 Burger H, van Daele $P$, Odding E, Valkenburg HA, Hofman $A$, Grobbee DE, et al. Association of radiographically evident osteoarthritis with higher bone mineral density and increased bone loss with age. Arthritis Rheum 1996;39:816.

23 Radin EL. Mechanical aspects of osteoarthritis. Bull Rheum Dis 1976;26:862-5.

24 Dequeker J, Mohan S, Finkelman RD, Aerssens J, Baylink DJ. Generalized osteoarthritis associated with increased insulin-like growth factor types I and II and transforming growth factor $\beta$ in cortical bone from the iliac crest. Arthritis Rheum 1993;36:1702-8.

25 Cauley JA, Gutai JP, Kuller LH, LeDonne D, Powell JG. The epidemiology of serum sex hormones in elderly women. Am $\mathcal{F}$ Epidemiol 1989;129:1 120-31.

26 Felson DT. Does excess weight cause osteoarthritis and, if so, why? Ann Rheum Dis 1996;55:000-000.

27 Spector TD, Perry LA, Jubb RW. Endogenous sex steroid levels in women with generalised osteoarthritis. Clin Rhew matol 1991;10:316-9.

28 Cauley J, Kwoh C, Egeland G, Nevitt MC, Cooperstein L Rohay J, et al. Serum sex hormones and severity of osteoarthritis of the hand. F Rheumatol 1993;20:1170-5.

29 Nevitt MC, Cummings SR, Lane NE, Genant HK, Pressman AR. Current use of oral estrogen is associated with a decreased prevalence of radiographic hip osteoarthritis in elderly white women [abstr]. Arthritis Rheum 1994;37(suppl):S212.

30 Hannan MT, Felson DT, Anderson J, Naimark A, Kannel WB. Estrogen use and radiographic osteoarthritis of the WB. Estrogen use and radiographic osteoarthritis
knee in women. Arthritis Rheum 1990;33:525-32.

31 Zhang YQ, McAlindon T, Hannan MT, Felson DT. A longitudinal study of the relation of estrogen replacemen therapy (ERT) to the risk of radiographic knee osteoarthritis (OA) [abstr]. Abstracts of the ACR National Scientific Meeting, 1995.

32 Oliveria J, Felson D. Estrogen replacement therapy and the development of osteoarthritis. Epidemiology (in press)
33 Cawley JA, Cummings SR, Black DM, Mascioli SR, Seeley DG. Prevalence and determinants of estrogen replacement therapy in elderly women. Am $\mathcal{f}$ Obstet Gynecol 1990; 163:1438-44.

34 Silberberg M, Sliberberg RH. Modifying action of estrogen on the evolution of osteoarthritis in mice of different ages. Endocrinology 1963;72:449-51.

35 Tsai CL, Liu TK. Estradial-induced osteoarthritis in ovariectomized rabbits. Clin Orthop Rel Res 1993;291:295-302.

36 Pelletier JP, DiBattista JA, Roughley P, McCollum $R$, Martel-Pelletier J. Cytokines and inflammation in cartilage degradation. Rheum Dis Clin North Am 1993;19:545.

37 Evans CH. Cartilage loss. In: Kuettner KE, Goldberg VM eds. Osteoarthritic disorders. Rosemont, II: Amercan Acadeds. Osteoarthritic disorders. Rosemont, IL: A
emy of Orthopedic Surgeons, 1995:271-80.

38 Pacifici R, Avioli LV. The effect of natural and surgical menopause on the secretion of cytokines from huma blood monocytes. Osteoporosis Int 1993;1993(supp 1):S106-7.

39 Manologas SC, Jilka RL. Bone marrow, cytokines and bone remodeling. N Engl ₹ Med 1995;332:305-11.

40 Nasatzky E, Schwartz Z, Soskolne WA, Brooks BP, Dean $\mathrm{DD}$, Boyan BD, et al. Evidence for receptors specific for 17B estradiol and testosterone in chondrocyte cultures. Conn Tiss Res 1994;30:277-94.

41 Guerne PA, Carson D, Lotz M. IL-6 production by human chondrocytes: modulation of its synthesis by cytokines growth factors and hormones in vitro. $f$ Immuno 1990;144:494- 505 .

42 Morales TI. The role of signaling factors in articular cartilage homeostasis and osteoarthritis. In: Kuettner KE, Goldberg VM, eds. Osteoarthritic disorders. Rosemont, II Amercan Academy of Orthopedic Surgeons, 1995:261 70.

43 Lieberman S, Mitchel A, Marcus R, Hintz RL, Hoffman AR. The insulin like growth factor I generation test: resistance to growth hormone with aging and estrogen replacement therapy. Horm Metab Res 1994;26:229-33.

44 Romagnoli E, Minisola S, Carnevale V, Scarda A, Rosso R Scarnecchia, et al. Circulating levels of insulin-like growth factor binding protein 3 (GFBP-3) and insulin-like growth factor 1 (IGF-1) in perimenopausal women. Osteoporosis Int 1994;4:305-8.

45 Dieppe P, Cushnaghan J, Young P, Kirwan J. Prediction of the progression of joint space narrowing in osteoarthritis of the knee by bone scintigraphy. Ann Rheum Dis of the knee by

46 Wolfe F, Altman R, Hochberg M, Lane N, Luggan M, Shar J. Postmenopausal estrogen therapy is associated with improved radiographic scores in osteoarthritis and $R A$ [abstr]. Arthritis Rheum 1994;37(suppl):S231.

47 Samanta A, Jones A, Regan M, Wilson S, Doherty M. Is osteoarthritis in women affected by hormonal changes or smoking? Br $\mathcal{F}$ Rheumatol 1993;32:366-70. 